\title{
Periodicals in science policy
}

The awakening of interest in the formulation of public policies for science and technology has led to the recent launching of specialized periodicals. This review, whilst by no means exhaustive, is intended to assist European physicists in following developments. Physicists who read these periodicals would be better informed of the level of discussion that governs decisions on science policy, and could determine how best to ensure that their interests are promoted.

\section{FUTURES}

A quarterly journal covering the development and application of forecasting techniques and long-term policy-making, FUTURES is published by IPC Science and Technology Press Ltd, UK, in co-operation with The Institute for the Future, USA. FUTURES is excellent background reading for the physicist/policy maker.

In the March 1971 issue of FUTURES, J.-J. Salomon, Head of the Science Policy Division of OECD wrote on 'Science Policy and its Myths'. The physicist who wants to understand the language of the science-policy makers would find the review of the relationship between technological forecasting and scientific research illuminating. Salomon indicated that the research system was 'still recalcitrant to efforts to rationalize it'. It was clear, in his opinion, that forecasting had not come to grips with fundamental research when he wrote

'if fundamental research is likely to be increasingly oriented, it is not because the forecasts in the name of which it is oriented will have any greater force of probability tomorrow than they have today, it is because what they determine as probable will be increasingly confused with what they deem, implicitly or explicitly, to be desirable.

'World Facts and Trends' by J. McHale appeared in the September and December 1971 issues. The 98-page article reviews the major themes of environment and society in transition : scientific developments: social consequences: policy implications, and ends with a note of guarded optimism :

'We should underline here, finally, that in terms of future options and alternatives the solution(s) to our most critical world problems are indeed well within our developing scientific and technological capabilities - but it will require a more massive undertaking than is presently evident in our pious hopes and traditional practices.

For example, our global defence establishments currently encompass a very large fraction of the highest scien- tific and technical expertise available in the world... One of the greatest priorities which now faces us is how we may turn such negative forces to positive advantage - to apply our co-operative energies to those human problems which threaten the very survival of our societies.'

In the March 1972 issue, K. Pavitt wrote 'Analytical Techniques in Government Science Policy'. Pavitt's concluding paragraphs are well worth quoting :

....we need to know more at the macrolevel about the political, social and economic factors which determine patterns of expenditure on science and technology, about the nature of the interaction between scientific and technological developments, about the factors which influence the output and diffusion of scientific and technological activities, about whether or not the current 'disillusionment' with science, technology and economic growth is anything more than the long-observed expression of the self-interest of a materially well-off minority, and about the relationships among technological progress, economic growth, resource use and the physical environment. It may be a very long time before we know enough about these phenomena to be able to measure them and to reduce the relationships among them to a relatively simple, manageable, quantifiable form. In the meantime, governments will continue to want better analytical inputs in their science policymaking processes. Formal analytical methods will no doubt have their role to play. But so will hard, empiricallybased and honest thinking about the specific characteristics of the policy problems under consideration.'

FUTURES, Dept A. D. F. 22, IPC House, 32 High Street, Guildford, Surrey, England.

\section{FUTURIBILI}

Published in Italian, this monthly journal contains articles on the future of all aspects of society together with summaries of the main contributions in English. In the March 1972 issue,
G. Nebbia writes of 'neotechnology and society'. His view is that

'The realization of a neotechnical society is impossible without highlevel planning and integration of private and public activity which free of pollution, represents an exciting challenge for ecologically aware politicians.

In the following issue, $V$. Selan examines the use of the world model des-. cribed in The Limits to Growth. He discusses the operative validity of the model as an 'alarm system' in the view of public opinion and world politicians. In another article, the ideas of S. Mansholt, President of the EEC Commission, on the problems arising from rapid population growth are summarized.

Futuribili, Via XX Settembre, I-00187 Roma.

\section{News Report}

News Report is published ten times each year and records the principal activities of the National Academy of Sciences, National Academy of Engineering, Institute of Medicine and National Research Council of the USA.

The summaries of New Publications of these bodies are often relevant to physics policy. For example, in the January 1972 issue, a report 'Atomic \& Molecular Physics' made out the case for Federal support for the field to be increased in the next three to five years by $\$ 8,200,000$. Also in 1972 , in the May issue, News Report summarizes the report 'The Science Committee' which describes the system adopted in the USA after a study of the questions :

'How should the practice of advising the government on scientific matters be modified to meet changing conditions ? How can service on advisory committees be made rewarding to members of a committee? How can we develop better balanced geographical, racial, and sexual representation on committees ? How can a committee guard against advice that is influenced by the self-interest of its members? As the social role of science and technology becomes more pervasive, how can the impartiality of committee advice be preserved ?'

One of the recommendations of 'The Science Committee' report is that the work of advising the government should be given greater visibility by more frequent reports to the scientific community and to the general public.

News Report, Office of Information, National Academy of Sciences, 2101 Constitution Avenue, Washington DC 20418, USA. 


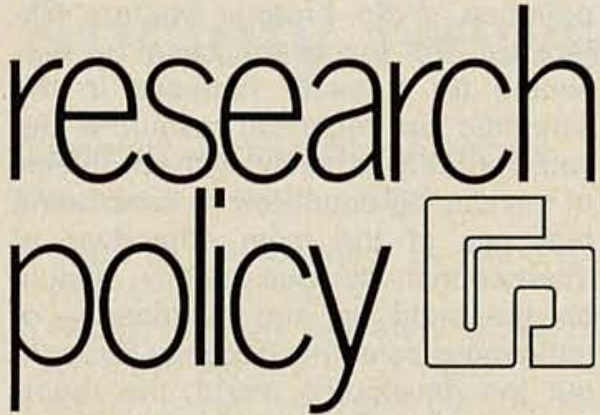

Launched in November 1971 by North-Holland Publishing Company, Research Policy is devoted to research policy, research management and planning and appears quarterly. The joint editors are C. Freeman and T.C. Sinclair (Science Policy Research Unit, The University of Sussex, UK) and $H$. Krauch and R. Coenen (Studiengruppe fur Systemforschung, Heidelberg, Federal Republic of Germany).

The first issue opens with an article by EPS President, H.B.G. Casimir on 'Industries and Academic Freedom' in which he outlines the attitude of university people and his view of the development of science and technology according to a 'spiral'. He also formulates some practical basic rules for industrialists in their dealings with universities, abbreviated here :

1 Do not try to influence programmes of basic work.

2 Do not try to determine the curriculum..

3 Straightforward development tasks are best done in your own laboratories...

4 ... I see no harm in industry suggesting certain themes of supporting work it is interested in, in a general way.

5 A university should never accept conditions of secrecy and industrial security.

6 Do not insist on exclusive rights to inventions.

7 Avoid under the table arrangements with one professor or scientific staff member.

Two complementary articles in the same issue are 'Lessons for the $\mathrm{Ob}$ jective Appraisal of Programmes at a National Level - Implications of Criteria and Policy' by P.M. Jones, and 'The Incorporation of Health and Welfare Risks into Technological Forecasting' by $C$. Sinclair. The first lesson from the contribution by Jones is

'At this point in time no coherent and purely objective approach to overall national priorities and strategies is possible. The tools are not yet available and the role of science in the economy is still imperfectly understood. Semiquantitative and partially subjective techniques exist that may help, with further development, to achieve improved resource allocation.'

Sinclair suggests a method of measuring and controlling the redistribu- tions of health and safety risks associated with industrial development in an economic and socially acceptable way so that both growth and quality of life may be preserved.

The second issue of Research Policy contains a paper by one of the Editors R. Coenen, on 'The Use of Technological Forescasting in Government Planning' which proposes what the author considers as two essential points challenging present arrangements for advising governments :

1 Technological forecasting cannot deal only with the technically feasible. Factors initiating processes of technological development and factors influencing the course of such processes have also to be taken into account, that is to say factors promoting innovation and factors impeding innovation. But such factors, the identification of which is the subject of innovation research, are mostly of a non-technological or non-scientific character. As mentioned above, the technological forecast must also take into consideration the social, economic and political implications of technological innovations. These statements may be regarded as trivial, but they gain in importance if one bears in mind that government agencies dealing with research planning usually obtain forecasts from advisory commissions whose members are exclusively natural scientists and technologists.

2 Therefore, it must be clearly emphasized that technological forecasting cannot be the task only of engineers and natural scientists. The participation of social scientists, economists and representatives of the social groups concerned, in my opinion, is an absolute necessity. This has so far not been fully recognized. It is possible to draw up a long catalogue of failures in technological forecasting made by natural scientists who were highly competent in their own fields.

The detailed analysis by $P$. Jervis in 'Innovation in Electron-Optical Instruments - Two British Case Histories' should perhaps be required reading by all physicists engaged in instrument development. The paper describes, in depth, the invention, development and commercial introduction of two scientific instruments, the scanning electron microscope and the X-ray microanalyser.

Research Policy, North-Holland Publishing Company, P.O. Box 211, Amsterdam, The Netherlands.

\section{strianga poligy}

Launched in January 1972 as a bimonthly publication of the Science Policy Foundation London, in collaboration with the Organization for Economic Co-operation and Development
(OECD), Paris, Science Policy was specifically designed as part of an integrated information system. The pages are perforated so that readers may collate sections in which they are interested.

By 'science policy' the Science Policy Foundation means a deliberate and coherent attempt to promote a basis for national and international decision influencing the size, institutional structure, resources and creativity of scientific research in relation especially to its application and public consequences.

Each issue is divided into eight sections: special articles, international digest, extended reports, Science Policy Foundation activities, OECD report, concern, facts-in-figures, and publications. Vol. 1 , No. 1 contained an useful article highlighting the salient points and implications of the Green Paper by the UK Government entitled 'A Framework for Government Research and Development', which underwent such vigorous discussion after its publication last November. The same problem in Israel was covered in another paper by E. Tal, Director of the National Council for Research and Development.

In the Extended Reports section of that issue, amongst subjects covered were: the new framework for technological innovation proposed for Japan; a summary of the state of scientific and technological research in Italy; European co-operation on research projects (agreed by 19 countries in November 1971); the main points from the French science budget for 1972 . The OECD report followed events at the Fourth Meeting of Ministers of Science in October 1971.

The second issue (March/April 1972) had three short articles. 'Science policy targets for $70 \mathrm{~s}$ : a Canadian plan of action' gave the 44 recommendations of the Special Committee on Science Policy. The committee apparently insists that the public must be brought into the debate, to be made more aware of the crucial importance of science and technology for the future of Canadians and mankind in general. 'UNISIST : A world science information system' is a one-page progress report by $H$. Coblans on the Unesco project for the internationalization of scientific information. Then, 'Developing countries: Financial resources for science and technology' describes the limitations on research and development in developing countries. It puts forward the view that each highly developed country should devote 5 per cent of its own internal non-military research and develop- 
ment expenditure to research for lesser developed countries, since these efforts are claimed to be four times as efficient as in the developing countries themselves. Extended Reports is again an invaluable feature with interesting items on: French atomic energy budget for 1972 ; Austria's increase in co-operation in international research ; a review of the report on Project SAPPHO (available from 162 Regent Street, London W1R 6DD at $75 \mathrm{p})$; and news of the reform of the Advisory Board on Education and Scientific Research in Fed. Rep. Germany.

The next issue of Science Policy (May / June 1972) carries a special article by D. Gabor on 'The New Responsibilities of Science.' Much of what he had written was based on the publication The Limits to Growth. However, whilst Gabor had some criticisms of the models and procedures used in the computer plots, he believed that one conclusion was inevitable: 'If we want to avoid a catastrophe in not more than one or at most, two hundred years, technology must take a new turn.'

Science Policy, Inforlink Ltd, 2A Station Road, Frimley, Surrey, U.K.

\section{SCIENCE STUDIES}

This quarterly journal has a learned approach to the subject of research in the social and historical dimensions of science and technology. Because of the range of topics for coverage, some issues would appear of special interest to physicists. For example, in October 1971, there were four contributions with such an appeal. A paper by $D$. Nelkin highlighted the conflicts that can arise between public policy and technical feasibility when both are on uncertain grounds.

As a result of pressure from a group of scientists and the impact of their views on public opinion, the construction of a nuclear pover station at Cayaga Lake in New York was postponed indefinitely in 1969. Nelkin maintains that crucial aspects of the scientific studies relating to the case were the absence of conclusive data and the lack of an accepted theoretical framework from which to draw definitive quantitative conclusions. These features meant that there was no 'objective evaluation' possible, so that the role of the scientific expert was questionable. On the other hand, those scientists who kept the issue in the public view by political action were criticized for being single-minded, mis leading with public information, and contributing to unnecessary polarization.

T.D. Lang, in 'The Government of Science: a Comparative Approach', compares the historical development of institutions making science policy. The overriding conclusion, in fact, is that not enough is known or published on science policy activities generally to permit exhaustive comparisons, either of nations or functional categories.

'The Widening Gap: Attitudes of First-Year Students and Staff towards Chemistry, Science, Careers and Commitment' is a frank appraisal by D. Zinberg. It sees the differing reactions of students and staff in the chemistry department at an English university in terms of national priorities and entry requirements in conflict with professional ethos and course contents. Much of the paper's analysis would probably apply in physics departments as well, so that it is a good guide for those concerned with education.

For professional physicists in the UK, the conclusions of the paper by E. Hutchinson on 'Government Laboratories and the Influence of Organized Scientists' must be encouraging :

'... when a body of first-rate scientists makes a concerted effort, it can resist the policies proposed by civil servants and, indeed, force its own will on the bureaucrats ; ... when a bureaucracy attempts to run a scientific activity without involving a large number of outside scientists, there is small likelihood that its scientific creature will be successful.'

The final contribution in this issue of Science Studies is a Discussion Paper by staff at Science Policy Research Unit, University of Sussex on 'The Goals of R \& D in the 70 s'.

The authors comment on the passage from growth in 1960 s to a hesitancy and slowing down in the 1970 s. They maintain that

'those who are more sympathetic to the achievements and the future promise of science and technology must examine realistically the sources of disquiet, and take this into account in the debates on policy for science in the 1970 s'.

The authors trace the decline in the relative importance of research for nuclear, space and military applications during the $1960 \mathrm{~s}$. They consider that economic growth has been the major preoccupation of most countries and that it is likely to remain so during the $1970 \mathrm{~s}$, although they discuss the limitations of growth unrelated to wider social objectives. They go on to point out how little of present scientific effort is in fact devoted to countering the threat of environmental pollution or to broader welfare objectives. An excellent case is presented for a major increase in the scientific and technical resources devoted entirely to resolving the problems of developing countries. In concluding that one of the main objectives of international science policy should be the build up and sustenance of indigenous scientific capacity throughout the developing world, the report stresses the great significance of fundamental research :

'Taking into account the educational, cultural, economic and political criteria, these appear to us to add up to a fairly strong justification for continued modest expansion of fundamental research, because of its critical contribution to all other parts of the science and technology system, including those whose growth we are strongly advocating in the 1970s. We reemphasize, however, that this is primarily a matter of values and non-quantitative judgement.'

Science Studies, Macmillan Journals Ltd., Little Essex Street, London WC2R 3LF.

UNIVERSITÉ DE L'ETTAT A MONS

\section{COURS A CONFÉRER}

Les cours suivants sont à conférer à l'Université de l'État à Mons (Belgique) :

1 Physique de l'état solide (licence en sciences physiques)

30 heures de cours +15 heures d'exercices +30 heures de travaux pratiques +30 heures de travaux pratiques (seulement pour l'orientation physique expérimentale).

2 Compléments de physique de l'état solide (licence en sciences physiques)

30 heures de cours +30 heures de travaux pratiques (seulement pour l'orientation physique expérimentale).

3 Eléments de physique de l'état solide (licence en sciences chimiques)

15 heures de cours (option).

Les enseignements ci-dessus sont susceptibles de former une chaire de "Physique expérimentale du solide".

Les candidats sont priés d'adresser leur demande et leur curriculum vitae, en double exemplaire, au Ministère de l'Education et de la Culture française, par l'intermédiaire de M. le Recteur de I'Université de l'État à Mons, 17, place Warocqué, 7000-MONS (Belgique). 